\title{
Penggunaan Media Kartu Kata untuk Meningkatkan Keterampilan Membaca Permulaan Mata Pelajaran Bahasa Indonesia Pada Siswa Kelas 1 SD Negeri 009 Rokan IV Koto Kabupaten Rokan Hulu Provinsi Riau
}

\author{
RIMHASNI \\ Guru SD Negeri 009 Rokan IV Koto \\ e-mail: @gmail.com
}

\begin{abstract}
This study aims to improve initial reading skills by using word card media. The location of the study was conducted at 009 Rokan IV Koto State Elementary School Rokan Hulu Regency, Riau Province with the subject of the study being 20th grade students. Data collection techniques used were tests and observation sheets. Based on the results of the analysis concluded that learning to begin with using the word card media can improve reading skills of grade 1 students at 009 Rokan IV Koto State Elementary School in 2019/2020. In this action the students' reading skills with pronunciation, intonation and reading comprehension increase until they reach the specified completeness criteria, namely with an average grade of 70 and $80 \%$ grade completeness.
\end{abstract}

Keywords: read the beginning, the word card media.

\begin{abstract}
ABSTRAK
Penelitian ini bertujuan untuk meningkatkan keterampilan membaca permulaan dengan menggunakan media kartu kata. Lokasi penelitian dilaksanakan di SD Negeri 009 Rokan IV Koto Kabupaten Rokan Hulu Provinsi Riau dengan subjek penelitian adalah siswa kelas I yang berjumlah 20 orang. Teknik pengumpulan data yang digunakan adalah tes dan lembar observasi. Berdasarkan hasil analisis disimpulkan bahwa pembelajaran membaca permulaan dengan menggunakan media kartu kata dapat meningkatkan keterampilan membaca siswa kelas 1 SD Negeri 009 Rokan IV Koto tahun pelajaran 2019/2020. Pada tindakan ini keterampilan membaca siswa dengan lafal, intonasi dan membaca memahami meningkat hingga mencapai kriteria ketuntasan yang ditetapkan yaitu dengan rata-rata kelas 70 dan ketuntasan kelas $80 \%$.
\end{abstract}

Kata Kunci: Membaca Permulaan, Media kartu kata.

\section{PENDAHULUAN}

Sekolah dasar (SD) merupakan salah satu lembaga jenjang pendidikan dasar yang berupaya mengembangkan kemampuan dan keterampilan siswa. Berbagai pengetahuan, pengalaman, dan keterampilan yang siswa peroleh dalam berbagai kegiatan yang dilaksanakan akan sebagai bekal belajar di tingkat pendidikan menengah.

Standar Isi satuan Pendidikan Dasar dan Menengah untuk kelas 1 SD (Depdiknas 2006:149) menjelaskan bahwa berbahasa dan bersastra meliputi empat aspek, yaitu: aspek mendengarkan, aspek berbicara, aspek membaca, aspek menulis. Keempat aspek kemampuan berbahasa dan bersastra tersebut memang berkaitan erat sehingga merupakan satu kesatuan yang tidak terpisahkan.

Berdasarkan pada standar isi satuan pendidikan dasar dan menengah untuk kelas satu pada mata pelajaran Bahasa Indonesia di Sekolah Dasar (Depdiknas 2006:148) bertujuan agar peserta didik mempunyai kemampuan sebagai berikut.

1. Berkomunikasi secara efektif dan efisien dengan etika yang berlaku baik lisan maupun tulisan,

2. Menghargai dan bangga menggunakan bahasa Indonesia sebagai bahasa persatuan dan bahasa negara,

3. Memahami bahasa Indonesia dan menggunakan dengan tepat dan kreatif untuk berbagai tujuan, 
4. Menggunakan bahasa Indonesia untuk meningkatkan intelektual serta kematangan emosional dan sosial,

5. Menikmati dan memanfaatkan karya sastra untuk memperluas wawasan, memperluas budi pekerti, meningkatkan pengetahuan dan keterampilan berbahasa,

6. Menghargai dan membanggakan sastra indonesia sebagai khasanah budaya dan intelektual manusia indonesia.

Keterampilan membaca yang diperoleh membaca permulaan sangat berpengaruh terhadap keterampilan membaca lanjut, sehingga keterampilan membaca permulaan sangat memerlukan perhatian guru. Karena membaca permulaan di kelas 1 merupakan pondasi bagi pengajaran selanjutnya. Sebagai pondasi haruslah kuat dan kokoh, oleh karena itu harus dilayani dan dilaksanakan secara berdaya guna dan sungguh-sungguh. Tujuan pelaksanaan membaca permulaan adalah supaya siswa bisa membaca kata-kata dan kalimat sederhana dengan lancar dan tepat.

Pembelajaran membaca yang dapat memberikan pengalaman pada peserta didik yaitu dengan melibatkan langsung peserta didik pada proses pembelajaran seperti permainan bahasa dan juga pemakaian media yang melibatkan siswa. Sehingga guru perlu menyediakan pembelajaran yang menarik yang bisa menimbulkan daya tarik bagi siswa untuk giat secara aktif dan kreatif. Pembelajaran membaca dengan Kompetensi Dasar yang di sampaikan adalah membaca lancar dan memahami beberapa kalimat sederhana yang terdiri dari 3 -5 kata dengan lafal dan intonasi yang tepat.

Namun hasil pengamatan peneliti di kelas 1 SD Negeri 009 Rokan IV Koto pembelajaran Bahasa Indonesia pada aspek membaca dengan penggunaan metode ceramah dan media papan tulis sudah baik, guru juga sudah memberikan contoh cara membaca kata dan kalimat dengan tepat, serta penggunaan lafal dan intonasi yang benar, tapi hasil keterampilan membaca siswa masih rendah. Rendahnya keterampilan membaca ini didapati dari hasil tes membaca nyaring dan membaca memahami dari 20 siswa 9 diantaranya membacanya masih belum tepat, hal ini dikarenakan perhatian siswa hanya terfokus hanya pada 15 menit awal, pada kegiatan inti siswa cenderung ribut, tidak dalam situasi belajar, sehingga materi yang disampaikan guru tidak terserap sepenuhnya dan dipahami oleh siswa. Guru juga sudah memberikan penjelasan maksud dari tulisan dengan lisan dan contoh di papan tulis, namun sebagian siswa masih belum paham jika disuruh menjawab soal dari pertanyaan yang terdapat dalam bacaan tersebut.

Siswa sudah dalam taraf mengenal huruf, tapi $45 \%$ atau 9 siswa masih kesulitan dalam membaca lancar dengan lafal dan intonasi yang tepat serta memahami maksud dari kata yang di baca. Hasil tes keterampilan membaca nyaring dengan aspek pengamatan ketepatan menyuarakan tulisan, lafal, intonasi serta kejelasan dalam membaca dan tes tertulis serta membaca memahami dengan menjawab beberapa pertanyaan dari cerita sederhana secara individual, nilai ratarata siswa masih dibawah Kriteria Ketuntasan Minimal (KKM) yaitu 66,50 sedangkan KKM yang ditetapkan yaitu 70 . Berdasarkan ratarata nilai persentase ketuntasan dari 20 siswa, ada sebanyak 9 atau $45 \%$ siswa yang belum tuntas.

Upaya untuk mengatasi keadaan demikian salah satunya adalah penggunaan media secara terintegrasi dalam proses belajar mengajar. Karena fungsi media dalam kegiatan tersebut disamping sebagai penyaji stimulus informasi, sikap dan meningkatkan keserasian dalam menerima informasi. Media juga berfungsi untuk mengatur langkah-langkah kemajuan serta untuk memberikan umpan balik pada proses belajar mengajar. Upaya yang dilaksanakan pada siswa kelas 1 SD Negeri 009 Rokan IV Koto untuk membangkitkan motivasi dan minat siswa, yaitu dengan media kartu kata dengan berbagai macam ejaan vokal, konsonan dan gabungan konsonan yang belum dikuasai siswa.

\section{KAJIAN TEORI}

\section{Keterampilan Membaca Permulaan}

Keterampilan membaca adalah kecakapan dalam menggunakan olah pikir 
dan perbuatan untuk melakukan aktifitas visual dengan menyuarakan rangkaian huruf menjadi kata dan kalimat dengan menguasai teknik membaca dan menangkap isi bacaan dengan baik.

Membaca permulaan adalah membaca yang dilaksanakan di kelas I dan II, dimulai dengan membaca huruf, kata, dan kalimat sederhana dan menitik beratkan pada aspek ketepatan menyuarakan tulisan, lafal dan intonasi yang wajar.

Pembelajaran membaca permulaan lebih ditekankan pada pengembangan kemampuan dasar membaca. Siswa dituntut untuk dapat menyuarakan huruf, suku kata, kata dan kalimat yang disajikan dalam bentuk tulisan ke dalam bentuk lisan. Tujuan membaca permulaan SD kelas 1 adalah agar siswa mampu membaca nyaring suku kata, kata dan kalimat sederhana dengan lafal dan intonasi yang tepat.

Faktor yang memengaruhi membaca permulaan adalah faktor fisikologis, faktor intelektual, faktor lingkungan, dan faktor psikologis. Faktor yang dapat mempengaruhi memampuan dalam membaca diantaranya faktor motivasi, faktor lingkungan keluarga, dan faktor bahan bacaan. Faktor yang mempengaruhi keberhasilan belajar membaca yaitu kematangan mental, kemampuan visual, kemampuan mendengarkan, perkembangan wicara dan bahasa, keterampilan berpikir dan memperhatikan, perkembangan motorik, kematangan sosial dan emosional, dan motivasi dan minat.

Media adalah alat bantu pengajaran dalam kegiatan belajar mengajar yang digunakan untuk menyampaikan pesan atau informasi. Media digunakan dalam kegiatan pembelajaran karena memiliki kemampuan untuk menyajikan peristiwa yang kompleks dan rumit menjadi lebih sistematik dan sederhana, meningkatkan daya tarik dan perhatian pembelajar, dan meningkatkan sistematika pembelajaran. Pembelajaran membaca permulaan, ada beberapa metode yang dapat digunakan yaitu abjad dan bunyi, kupas rangkai suku kata dan kata lembaga, metode global, SAS (Struktural Analitik Sintetik).
Materi yang diajarkan dalam membaca permulaan yaitu: 1) Lafal dan intonasi kata dan kalimat sederhana. 2) Huruf-huruf yang banyak digunakan dalam kata dan kalimat sederhana yang sudah dikenal siswa (hurufhuruf diperkenalkan secara bertahap dengan 14 huruf). 3) Kata-kata baru yang bermakna (menggunakan huruf-huruf yang sudah dikenal), misalnya: toko, ubi, boneka, mata, tamu. 4) Lafal dan intonasi kata yang sudah dikenal dan kata baru. 5) Puisi yang sesuai dengan tingkat kemampuan dan usia siswa. 6) Bacaan lebih kurang 10 kalimat (dibaca dengan lafal dan intonasi yang wajar).

\section{Media Kartu Kata}

Media adalah alat yang digunakan untuk menyalurkan pesan atau informasi dari pengirim kepada penerima pesan, kemudian media pembelajaran adalah segala sesuatu yang dapat di gunakan guru untuk menyalurkan pesan kepada peserta didik sehingga dapat merangsang pikiran, perasaan, perhatian dan minat siswa dan mempunyai pengalaman yang nyata sehingga dapat meningkatkan proses dan hasil belajar siswa.

Media pembelajaran adalah perantara dari pengirim kepada penerima pesan, selanjutnya media pembelajaran adalah suatu alat yang digunakan dalam pembelajaran yang dapat membangkitkan keinginan dan minat baru, meningkatkan motivasi dan rangsangan kegiatan belajar, dan berpengaruh secara psikologis kepada siswa sehingga dalam proses belajar mengajar lebih efektif dan efisien.

Media visual adalah alat yang digunakan untuk menyalurkan pesan dari sumber ke penerima pesan melalui panca indra visual penglihatan. Pesan yang akan disampaikan dituangkan ke dalam simbol-simbol visual. Selain itu, fungsi media visual adalah untuk menarik perhatian, memperjelas sajian ide, menggambarkan atau menghiasi fakta yang mungkin akan cepat dilupakan apabila pesan tersebut jika tidak divisualkan.

Pembelajaran membaca permulaan guru dapat menggunakan strategi bermain dengan memanfaatkan kartu gambar dan kartu kata. 
Kartu kata tersebut digunakan sebagai media dalam permainan menemukan kalimat, siswa diajak bermain dengan menyusun kata-kata menjadi sebuah kalimat yang berdasarkan teka-teki atau soal-soal yang dibuat oleh guru. Langkah langkah menggunakan media kartu kata dalam pembelajaran membaca siswa di kelas 1 adalah sebagai berikut.

1. Memanfaatkan benda kongkret yang ada disekitar siswa untuk dijadikan sumber belajar siswa dalam membaca.

2. Menghubungkan antara materi membaca dengan benda-benda kongkret yang ada di lingkungan sekitar siswa. Siswa menyusun kartu kata berdasarkan nama-nama bendabenda kongkret yang ditemukannya sehingga membentuk kalimat.

3. Siswa membaca/mengeja kata-kata atau kalimat yang telah ditemukannya pembelajaran dapat dilaksanakan sesuai prosedur (tematik untuk kelas rendah) misalnya mulai dari bercerita, menyanyi, atau tanya jawab.

4. guru menanyakan beberapa kata yang terkait dengan alat traspotasi kepada kelas secara umum setiap kata yang disebutkan anak, guru menempel kartu kata di papan planel, kemudian meminta anak untuk mengulangi mengucapkan kata tadi bersama-sama variasi mengucapkan kata bisa dilakukan, misalnya dengan menanyakan ke seluruh kelas, bisa menyuruh beberapa siswa membaca, atau menanyakan kepada siswa bagaimana membacanya, $\mathrm{k}$ egiatan ini dilakukan hingga semua kata terkait tema yang sudah disiapkan dapat ditempel di papan planel,

5. selanjutnya, guru menyuruh siswa berlatih membaca kata-kata yang tertempel di papan planel dalam hati, waktu kira-kira 10 menit yang belum tahu bagaimana membacanya dapat bertanya kepada teman di sebelahnya,

6. guru dapat menugasi beberapa siswa untuk memilih beberapa kata yang tertempel, kemudian mencari pasangannya yaitu kartu suku kata, kartu suku kata ini dipasang di bawah kartu kata dan siswa membacanya keras-keras,
7. Guru membagi siswa di kelas menjadi beberapa kelompok. Masing-masing kelompok mencari kelompok lain sebagai pasangan bermain. Satu kelompok mengambil dua atau tiga kata dari yang tertempel di papan, kemudian kelompok lainnya membuat kalimat berdasarkan katakata yang dipilihkan oleh kelompok lain. Harus dipastikan bahwa setiap kelompok mendapatkan giliran memilih kartu kata dan membuat kalimat berdasarkan kartu kata terpilih.

\section{METODOLOGI PENELITIAN \\ Subjek dan Objek Penelitian}

Subjek dalam penelitian tindakan kelas ini adalah guru dan siswa kelas 1 SD Negeri 009 Rokan IV Koto Kabupaten Rokan Hulu dengan jumlah siswa 20 orang. Sedangkan objek dalam penelitian ini adalah penggunaan metode kartu kata dalam meningkatkan keterampilan membaca pada mata pelajaran Bahasa Indonesia.

\section{Rencana Tindakan}

Penelitian ini adalah penelitian tindakan kelas (PTK) yang melalui langkah-langkah yaitu perencanaan, pelaksanaan, pengamatan dan refleksi. Penelitian ini direncanakan dua siklus. Siklus pertama diawali dengan refleksi awal karena peneliti telah memiliki data yang dapat dijadikan dasar untuk merumuskan tema penelitian yang selanjutnya diikuti perencanaan tindakan, pelaksanaan tindakan, pengamatan dan refleksi.

Perencanaan tindakan kelas ini adapun hal-hal yang dipersiapkan adalah: Menyusun RPP berdasarkan standar kompetensi dengan langkah-langkah penggunaan metode kartu kata. Meminta kesediaan teman sejawat (observer), Menyusun format pengamatan (lembar observasi) tentang aktifitas guru selama proses pembelajaran berlangsung dan Menyusun format pengamatan tentang keterampilan membaca siswa.

Observasi yaitu penelitian yang dilakukan melalui pengamatan dan pencatatan terhadap gejala yang tampak pada objek penelitian ditempat berlangsungnya peristiwa dan peneliti berada bersamaan objek yang diteliti. 
Berdasarkan hasil dari pengamatan yang dilakukan penulis melakukan diskusi dengan observer, hasil dari pengamatan dan diskusi tersebut penulis melakukan refleksi diri untuk mengetahui keberhasilan tindakan dan merencanakan tindakan selanjutnya.

\section{Teknik Analisa Data}

Analisa data yang digunakan adalah dengan penganalisaan secara deskriptif kuantitatif terhadap aktivitas guru dan aktivitas siswa. Penelitian deskriptif kuantitatif merupakan data yang diperoleh dari sampel populasi penelitian dianalisis sesuai dengan metode statistik yang digunakan.

Pengukurannya adalah dengan melihat persentase aktivitas guru dan aktivitas siswa, maka data yang diperoleh diinterprestasikan sesuai dengan tujuan penelitian yang dilakukan dengan menggunakan rumus :

$$
P=\frac{F}{N} x 100 \%
$$

$$
\begin{aligned}
& \text { Keterangan : } \\
& \mathrm{P} \quad \text { = Persentase hasil pengukuran } \\
& \mathrm{F} \quad \text { = Skor yang diperoleh } \\
& \mathrm{N} \quad \text { = Jumlah keseluruhan } \\
& 100 \quad \text { Bilangan tetap }
\end{aligned}
$$

\section{Analisis Aktivitas Guru}

Adapun aktivitas guru dalam proses pembelajaran dengan penggunaan metode kartu kata yang terdiri atas 5 indikator Pengukurannya adalah dengan melihat persentase tingkat kesempurnaan aktivitas yang dilakukan guru, maka data yang diperoleh diinterprestasikan sesuai dengan tujuan penelitian yaitu:

$$
\begin{aligned}
& \text { Sangat sempurna } \quad: \quad 81 \%-100 \% \\
& \text { Sempurna : } 61 \%-80 \% \\
& \text { Cukup Sempurna : } 41 \%-60 \% \\
& \text { Kurang sempurna : } 21 \%-40 \% \\
& \text { Tidak sempurna : } 0 \%-20 \% \text {. }
\end{aligned}
$$

Aktivitas guru dikatakan sesuai dan berhasil apabila aktivitas yang dilakukan telah sesuai dengan langkah-langkah metode kartu kata yang disusun dalam RPP, dengan kategori

\begin{tabular}{|c|c|}
\hline Sangat Tinggi & $81 \%-100 \%$ \\
\hline Tinggi & $61 \%-80 \%$ \\
\hline Sedang & $41 \%-60 \%$ \\
\hline Rendah & $21 \%-40 \%$ \\
\hline Sangat Rendah & $0 \%-20 \%$ \\
\hline
\end{tabular}
sempurna antara rentang $61 \%-80 \%$.

\section{Analisis Aktivitas Siswa}

Data aktivitas belajar siswa berguna untuk mengetahui kegiatan belajar telah sesuai dengan harapan. Indikator aktivitas belajar siswa dipersentasekan sesuai dengan kebutuhan penelitian. Pengukurannya adalah dengan melihat persentase kegiatan yang dilakukan siswa. Data yang diperoleh diinterprestasikan sesuai dengan tujuan penelitian yaitu:

Aktivitas siswa yang diharapkan dalam penelitian ini adalah apabila siswa dalam belajar berada pada tingkatan klasifikasi "tinggi" antara rentang 61\% - 80\%.

\section{Analisis Hasil Keterampilan Membaca}

Teknik analisis data keterampilan membaca dalam penelitian ini adalah statistik deskriptif dengan mencari rerata. Nilai dinalisis menggunakan statistik deskriptif yaitu dengan mencari rerata dengan rumus sebagai berikut:

$M_{x}=\frac{\sum x}{N}$

Keterangan:

$M_{x} \quad=$ rerata

$\sum x=$ jumlah total nilai siswa

$N \quad=$ jumlah siswa

Setelah menentukan ketuntasan individu, maka ditentukan persentase ketuntasan klasikal, dengan rumus :

$$
K K=\frac{J S T}{J S} x 100 \%
$$

Keterangan:

$\mathrm{KK}=$ Persentase Ketuntasan Klasikal

JST = Jumlah Siswa yang Tuntas

JS = Jumlah Siswa Keseluruhan

\section{HASIL DAN PEMBAHASAN}

Berdasarkan hasil pengamatan yang dilakukan terhadap aktivitas yang dilakukan guru pada siklus pertama dalam pelaksanaan pembelajaran pertemuan pertama diperoleh persentase aktivitas guru sebesar 59,38\%, dengan hasil pengamatan yang telah dilakukan 
dapat dilihat pada tabel berikut.

Tabel Hasil Observasi Aktivitas Guru Pertemuan 1 Siklus I

\begin{tabular}{|c|l|c|c|c|c|}
\hline \multirow{2}{*}{ No } & \multicolumn{1}{|c|}{ Aktivitas guru yang diamati } & \multicolumn{3}{c|}{ Hasil pengamatan } \\
\hline & \multicolumn{1}{|c|}{$\mathbf{1}$} & $\mathbf{2}$ & $\mathbf{3}$ & $\mathbf{4}$ \\
\hline 1 & Melakukan apersepsi & & & $\sqrt{ }$ & \\
\hline 2 & Menjelaskan tujuan pembelajaran & & & $\sqrt{ }$ & \\
\hline 3 & Menjelaskan materi & & & $\sqrt{ }$ & \\
\hline 4 & Menjelaskan tentang kartu kata & & $\sqrt{ }$ & & \\
\hline 5 & Menjelaskan cara mempergunakan kartu kata & & $\sqrt{ }$ & & \\
\hline 6 & Membimbing siswa dalam mempergunakan kartu kata & & & \\
\hline 7 & Memberikan kesempatan siswa untuk menggunakan kartu kata & & $\sqrt{ }$ & & \\
\hline 8 & Menumbuhkan partisipasi aktif siswa & & $\sqrt{ }$ & & \\
\hline 9 & Membagi siswa untuk kegiatan membaca & & $\sqrt{ }$ & & \\
\hline 10 & Mengelilingi siswa untuk memberikan arahan dan bimbingan & & $\sqrt{ }$ & \\
\hline 11 & Membahas jawaban soal bersama-sama & & & $\sqrt{ }$ & \\
\hline 12 & $\begin{array}{l}\text { Memberikan kesempatan siswa untuk menyelesaikan soal } \\
\text { individu }\end{array}$ & & & & $\sqrt{ }$ \\
\hline 13 & Melakukan pemeriksaan terhadap hasil individu siswa & & & \\
\hline 14 & Memberikan penghargaan terhadap hasil tes individu siswa & & $\sqrt{ }$ & \\
\hline 15 & Melaksanakan pembelajaran sesuai dengan tujuan yang dicapai & & $\sqrt{ }$ & \\
\hline 16 & Memberikan kesimpulan materi yang di ajarkan & & $\sqrt{ }$ & \\
\hline Jumlah skor & & 20 & 18 & \\
\hline Skor maksimum & & $\mathbf{6 4}$ & \\
\hline Persentase Nilai(Jumlah skor di bagi Skor maksimum)x100\% & $\mathbf{3 8 : 6 4 x 1 0 0 \% = 5 9 , 3 8}$ \\
\hline Kategori & & $\mathbf{\%}$ \\
\hline
\end{tabular}

Keterangan: Skor 4 : Sangat Sempurna

Skor 3 : Sempurna

Skor 2 : Cukup sempurna

Skor 1 : Kurang Sempurna

Hasil penjumlahan terhadap seluruh aktivitas yang dilakukan guru pada pertemuan pertama yaitu dengan jumlah 38 artinya $59,38 \%$ aktivitas guru berada pada kategori "Cukup Sempurna" antara rentang 41\% -

60\%. Selanjutnya pertemuan kedua dengan persentase $65,63 \%$, dengan hasil pengamatan yang telah dilakukan dapat dilihat pada tabel berikut ini.

Tabel Hasil Observasi Aktivitas Guru Pertemuan 2 Siklus I

\begin{tabular}{|c|l|c|c|c|c|}
\hline \multirow{2}{*}{ No } & \multicolumn{1}{|c|}{ Aktivitas guru yang diamati } & \multicolumn{3}{|c|}{ Hasil pengamatan } \\
\cline { 3 - 6 } & \multicolumn{1}{|c|}{$\mathbf{1}$} & $\mathbf{2}$ & $\mathbf{3}$ & $\mathbf{4}$ \\
\hline 1 & Melakukan apersepsi & & & $\sqrt{ }$ & \\
\hline 2 & Menjelaskan tujuan pembelajaran & & & $\sqrt{ }$ & \\
\hline 3 & Menjelaskan materi & & & $\sqrt{ }$ & \\
\hline 4 & Menjelaskan tentang kartu kata & & & $\sqrt{ }$ & \\
\hline 5 & Menjelaskan cara mempergunakan kartu kata & & & $\sqrt{ }$ & \\
\hline 6 & Membimbing siswa dalam mempergunakan kartu kata & & $\sqrt{ }$ & \\
\hline 7 & Memberikan kesempatan siswa untuk menggunakan kartu kata & & & $\sqrt{ }$ & \\
\hline 8 & Menumbuhkan partisipasi aktif siswa & & $\sqrt{ }$ & & \\
\hline 9 & Membagi siswa untuk kegiatan membaca & & & $\sqrt{ }$ & \\
\hline
\end{tabular}




\begin{tabular}{|c|l|c|c|c|c|}
\hline 10 & Mengelilingi siswa untuk memberikan arahan dan bimbingan & $\sqrt{ }$ & \\
\hline 11 & Membahas jawaban soal bersama-sama & & & $\sqrt{ }$ & \\
\hline 12 & $\begin{array}{l}\text { Memberikan kesempatan siswa untuk menyelesaikan soal } \\
\text { individu }\end{array}$ & \multicolumn{2}{|c|}{$\sqrt{ }$} & \\
\hline 13 & Melakukan pemeriksaan terhadap hasil individu siswa & & & $\sqrt{ }$ & \\
\hline 14 & Memberikan penghargaan terhadap hasil tes individu siswa & & $\sqrt{ }$ & \\
\hline 15 & Melaksanakan pembelajaran sesuai dengan tujuan yang dicapai & $\sqrt{ }$ & \\
\hline 16 & Memberikan kesimpulan materi yang di ajarkan & $\sqrt{ }$ & & \\
\hline Jumlah skor & \multicolumn{3}{|c|}{$\mathbf{6 4}$} & 30 \\
\hline Skor maksimum & $\mathbf{4 2 : 6 4 x 1 0 0 \% = 6 5 , 6 3}$ \\
\hline Persentase Nilai(Jumlah skor di bagi Skor maksimum)x100\% & \multicolumn{3}{|c|}{ Sempurna } \\
\hline
\end{tabular}

Keterangan: Skor 4 : Sangat Sempurna

Skor 3 : Sempurna

Skor 2 : Cukup sempurna

Skor 1 : Kurang Sempurna

Hasil penjumlahan terhadap seluruh aktivitas yang dilakukan guru pada pertemuan kedua yaitu dengan jumlah 42 artinya $65,63 \%$ aktivitas guru berada pada kategori "Sempurna" antara rentang $61 \%$ - 80\%.

Siklus ke II pertemuan ke 3 diperoleh persentase $79,69 \%$, dengan hasil pengamatan yang telah dilakukan dapat dilihat pada tabel berikut ini.

Tabel Hasil Observasi Aktivitas Guru Pertemuan 3 Siklus II

\begin{tabular}{|c|c|c|c|c|c|}
\hline \multirow{2}{*}{ No } & \multirow{2}{*}{ Aktivitas guru yang diamati } & \multicolumn{4}{|c|}{ Hasil pengamatan } \\
\hline & & 1 & 2 & 3 & 4 \\
\hline 1 & Melakukan apersepsi & & & & $\sqrt{ }$ \\
\hline 2 & Menjelaskan tujuan pembelajaran & & & & $\sqrt{ }$ \\
\hline 3 & Menjelaskan materi & & & & $\sqrt{ }$ \\
\hline 4 & Menjelaskan tentang kartu kata & & & $\sqrt{ }$ & \\
\hline 5 & Menjelaskan cara mempergunakan kartu kata & & & $\sqrt{ }$ & \\
\hline 6 & Membimbing siswa dalam mempergunakan kartu kata & & & $\sqrt{ }$ & \\
\hline 7 & Memberikan kesempatan siswa untuk menggunakan kartu kata & & & $\sqrt{ }$ & \\
\hline 8 & Menumbuhkan partisipasi aktif siswa & & & $\sqrt{ }$ & \\
\hline 9 & Membagi siswa untuk kegiatan membaca & & & $\sqrt{ }$ & \\
\hline 10 & Mengelilingi siswa untuk memberikan arahan dan bimbingan & & & $\sqrt{ }$ & \\
\hline 11 & Membahas jawaban soal bersama-sama & & & $\sqrt{ }$ & \\
\hline 12 & $\begin{array}{l}\text { Memberikan kesempatan siswa untuk menyelesaikan soal } \\
\text { individu }\end{array}$ & & & $\sqrt{ }$ & \\
\hline 13 & Melakukan pemeriksaan terhadap hasil individu siswa & & & $\sqrt{ }$ & \\
\hline 14 & Memberikan penghargaan terhadap hasil tes individu siswa & & & $\sqrt{ }$ & \\
\hline 15 & Melaksanakan pembelajaran sesuai dengan tujuan yang dicapai & & & $\sqrt{ }$ & \\
\hline 16 & Memberikan kesimpulan materi yang di ajarkan & & & $\sqrt{ }$ & \\
\hline \multicolumn{2}{|r|}{ Jumlah skor } & & & 39 & 12 \\
\hline \multirow{2}{*}{\multicolumn{2}{|c|}{ Persentase Nilai(Jumlah skor di bagi Skor maksimum)x100\% }} & \multicolumn{4}{|c|}{64} \\
\hline & & \multicolumn{4}{|c|}{$\begin{array}{c}51: 64 \times 100 \%=79,69 \\
\%\end{array}$} \\
\hline \multicolumn{2}{|r|}{ Kategori } & \multicolumn{4}{|c|}{ Sempurna } \\
\hline
\end{tabular}


Keterangan: $\quad$ Skor 4 : Sangat Sempurna

Skor 3 : Sempurna

Skor 2 : Cukup sempurna

Skor 1 : Kurang Sempurna

Hasil penjumlahan terhadap seluruh aktivitas yang dilakukan guru pada pertemuan ketiga yaitu dengan jumlah 51 artinya $79,69 \%$ aktivitas guru berada pada kategori

setelah pertemuan keempat terlaksana $92,19 \%$, dengan hasil pengamatan yang telah dilakukan dapat dilihat pada tabel berikut ini.

"Sempurna" antara rentang 61\% -80\%. Dan

Tabel Hasil Observasi Aktivitas Guru Pertemuan 4 Siklus II

\begin{tabular}{|c|c|c|c|c|c|}
\hline \multirow{2}{*}{ No } & \multirow{2}{*}{ Aktivitas guru yang diamati } & \multicolumn{4}{|c|}{ Hasil pengamatan } \\
\hline & & 1 & 2 & 3 & 4 \\
\hline 1 & Melakukan apersepsi & & & & $\sqrt{ }$ \\
\hline 2 & Menjelaskan tujuan pembelajaran & & & & $\sqrt{1}$ \\
\hline 3 & Menjelaskan materi & & & & $\sqrt{ }$ \\
\hline 4 & Menjelaskan tentang kartu kata & & & & $\sqrt{ }$ \\
\hline 5 & Menjelaskan cara mempergunakan kartu kata & & & & $\sqrt{ }$ \\
\hline 6 & Membimbing siswa dalam mempergunakan kartu kata & & & & $\sqrt{ }$ \\
\hline 7 & Memberikan kesempatan siswa untuk menggunakan kartu kata & & & & $\sqrt{ }$ \\
\hline 8 & Menumbuhkan partisipasi aktif siswa & & & $\sqrt{ }$ & \\
\hline 9 & Membagi siswa untuk kegiatan membaca & & & & $\sqrt{ }$ \\
\hline 10 & Mengelilingi siswa untuk memberikan arahan dan bimbingan & & & $\sqrt{ }$ & \\
\hline 11 & Membahas jawaban soal bersama-sama & & & & $\sqrt{ }$ \\
\hline 12 & $\begin{array}{l}\text { Memberikan kesempatan siswa untuk menyelesaikan soal } \\
\text { individu }\end{array}$ & & & $\sqrt{ }$ & \\
\hline 13 & Melakukan pemeriksaan terhadap hasil individu siswa & & & & $\sqrt{ }$ \\
\hline 14 & Memberikan penghargaan terhadap hasil tes individu siswa & & & $\sqrt{ }$ & \\
\hline 15 & Melaksanakan pembelajaran sesuai dengan tujuan yang dicapai & & & $\sqrt{ }$ & \\
\hline 16 & Memberikan kesimpulan materi yang di ajarkan & & & & $\sqrt{ }$ \\
\hline \multicolumn{2}{|r|}{ Jumlah skor } & & & 15 & 44 \\
\hline \multicolumn{2}{|r|}{ Skor maksimum } & \multicolumn{4}{|c|}{64} \\
\hline \multicolumn{2}{|r|}{ Persentase Nilai(Jumlah skor di bagi Skor maksimum)x100\% } & \multicolumn{4}{|c|}{$\begin{array}{c}59: 64 \times 100 \%=92,19 \\
\%\end{array}$} \\
\hline \multicolumn{2}{|r|}{ Kategori } & \multicolumn{4}{|c|}{ Sangat Sempurna } \\
\hline
\end{tabular}

Keterangan: Skor 4 : Sangat Sempurna

Skor 3 : Sempurna

Skor 2 : Cukup sempurna

Skor 1 : Kurang Sempurna

Hasil penjumlahan terhadap seluruh aktivitas yang dilakukan guru pertemuan keempat yaitu dengan jumlah 64 artinya 92,19\% aktivitas guru berada pada kategori "Sangat Sempurna" antara rentang $81 \%-100 \%$. Persentase tingkat kesempurnaan aktivitas yang dilakukan guru setiap pertemuan terus meningkat dan sudah berada pada klasifikasi "Sangat sempurna".
Penggunaan metode kartu kata yang dilakukan guru dalam proses pembelajaran ternyata juga mempengaruhi aktivitas siswa dalam belajar. Hasil observasi aktivitas siswa pada siklus I pertemuan pertama dengan persentase keaktifan siswa mencapai $57,81 \%$ berada pada kategori "Sedang" dan pada pertemuan kedua mencapai $64,06 \%$ berada 
pada kategori "Tinggi”. Sedangkan pada siklus ke II aktivitas siswa meningkat pada pertemuan ke 3 dengan persentase $79,69 \%$ berada pada kategori "Tinggi" dan pertemuan ke 4 mencapai $90,63 \%$ berada pada kategori "Sangat Tinggi". Aktivitas kegiatan belajar siswa setiap pertemuan juga terus meningkat dan telah sesuai dengan harapan berada pada klasifisakasi "Sangat tinggi".

Hasil evaluasi penilaian keterampilan membaca siswa siklus I setelah penggunaan metode kartu kata, diperoleh penurunan jumlah siswa yang bernilai rendah (di bawah $\mathrm{KKM}$ ) dan telah terjadi peningkatan jumlah siswa yang benilai tinggi (di atas KKM). Perolehan nilai data awal siswa yang bernilai di atas KKM hanya 11 orang $(55,00 \%)$ dengan rata-rata nilai 66,50 , setelah siklus I terjadi peningkatan hingga 15 orang $(75,00 \%)$ dengan rata-rata nilai 69,75 , setelah siklus ke II lebih meningkat telah mencapai 19 orang $(95,00 \%)$ dari 20 orang siswa dengan rata-rata nilai 77,75 .

Hasil tindakan pada siklus I dan II diperolehlah bahwa hasil observasi aktivitas guru dan siswa yang selalu meningkat pada proses pembelajaran metode kartu kata mengakibatkan pula pada peningkatan keterampilan membaca siswa, maka hipotesis melalui metode kartu kata untuk meningkatkan keterampilan membaca permulaan mata pelajaran Bahasa Indonesia pada siswa kelas 1 SD Negeri 009 Rokan IV Koto Kabupaten Rokan Hulu dapat diterima. Artinya jika diterapkan metode kartu kata secara benar maka siswa akan berhasil dalam keterampilan membaca permulaan.

\section{KESIMPULAN DAN SARAN}

Berdasarkan hasil analisis dan pembahasan yang dilakukan membuktikan bahwa penggunaan metode kartu kata dapat meningkatkan keterampilan membaca permulaan mata pelajaran Bahasa Indonesia pada siswa kelas I SD Negeri 009 Rokan IV Koto Kabupaten Rokan Hulu tahun pelajaran 2019/2020.

Bertitik tolak dari kesimpulan dan pembahasan hasil penelitian, berkaitan dengan penggunaan metode kartu kata, peneliti mengajukan beberapa saran yaitu: Pembelajaran membaca permulaan yang menggunakan media kartu kata hendaknya menggunakan variasi warna dan ukuran yang sesuai agar dapat menarik perhatian dan memperjelas pandangan siswa. Pembelajaran membaca permulaan dengan menggunakan media kartu kata hendaknya menggunakan kata yang bervariasi agar siswa mempunyai keterampilan dalam membaca dengan berbagai gabungan huruf. Sebaiknya guru lebih memperkaya pengetahuan tentang caracara mengajar supaya kelas menjadi lebih hidup dan siswa lebih meningkat hasil belajarnya.

\section{DAFTAR PUSTAKA}

Ahmad Rohani. (1997). Media Instruksional Edukatif. Jakarta: Rineka Cipta.

Ahmad Rofiecuddin, dan Darmiyati Zuhdi. (1998). Pendidikan Bahasa dan Sastra Indonesia di Kelas Tinggi. Departemen Pendidikan dan Kebudayaan Direktorat Jenderal Pendidikan Tinggi Proyek Pendidikan Guru Sekolah Dasar.

Atwi Suparman. M. (2001). Desain instruksional. Jakarta: Proyek Pengembangan Universitas Terbuka, Direktorat Jendral Pendidikan Tinggi, Departemen Pendidikan Nasional.

Arief S. Sadiman. (2009). Media Pendidikan. Jakarta: PT Raja Grafindo Persada.

Azhar Arsyad. (2007). Media Pembelajaran. Jakarta : RajaGrafindo Persada.

Darmiyati Zuchdi dan Budiasih. (2001). Pendidikan Bahasa dan Sastra Indonesia di Kelas Rendah. Yogyakarta: PAS.

Dwi Sunar Prasetyono. (2008). Rahasia Mengajarkan Gemar Membaca pada Anak Sejak Dini. Yogyakarta: Think Yogyakarta.

Djauzak Ahmad, dkk. (1996). Metodik Khusus Pengajaran Bahasa Indonesia di Sekolah Dasar. Jakarta: Dirjen Pendidikan Dasar Departemen Pendidikan Nasional.

Depdiknas. (2006). Peraturan Menteri Pendidikan Nasional RI No.22 Tahun 2006 tentang Standar Isi Untuk Satuan Pendidikan Dasar dan Menengah. Jakarta: Depdiknas.

Farida Rahim. (2007). Dasar Pengajaran membaca di Sekolah. Jakarta: Bumi Aksara. 
Henry Guntur Tarigan. (2008). Membaca sebagai Suatu Keterampilan Berbahasa. Bandung: Angkasa Group.

Hairudin. dkk. (2007). Pembelajaran Bahasa Indonesia Direktorat Jendral Pendidikan Tinggi. Departemen Pendidikan Nasional. Mulyono Abdurrahman. (2003). Pendidikan Bagi Anak Berkesulitan. Jakarta: Rineka Cipta.

M. Dalyono. (2009). Psikologi Pendidikan. Jakarta: Rineka Cipta.

Nuriadi. (2008). Teknik Jitu Menjadi Pembaca Teramp il. Yogya karta: Pu staka Pelajar.

Parjono. (2007). Panduan Penelitian Tindakan Kelas. Lembaga Penelitian UNY. Karangmalang Yogyakarta.

St. Y Slamet. (2007). Dasar-Dasar Pembelajaran Bahasa dan Sastra Indonesia di Sekolah Dasar. Surakarta: UNS Press.

Subana. (2000). Statistik Pendidikan. Bandung: Pustaka Setia.

Saleh Abbas. (2006). Pembelajaran Bahasa Indonesia Yang Efektif di Sekolah Dasar. Direktorat Jendral Pendidikan Tinggi. Departemen Pendidikan Nasional.

Suharsimi Arikunto, dkk. (2008). Penelitian Tindakan Kelas. Jakarta: Bumi Aksara.

Uemar Hamalik. (1994). Media Pendidikan, cetakan ke-7. Bandung: Penerbit PT. Citra Aditya Bakti.

Winihasih. (2005). D iagnosis Kesulitan Belajar Membaca Permulaan Siswa SD/MI Melalui Analisis Reading Readiness. Jurnal Sekolah Dasar.

Yusfhadi, Miarso. (2007). Menyemai Benih Teknologi Pendidikan. Cetakan Ketiga. Jakarta: Kencana Prenada Media Group. 